IRA-International Journal of Applied Sciences

ISSN 2455-4499; Vol.03, Issue 03 (2016)

Institute of Research Advances

http://research-advances.org/index.php/IRAJAS

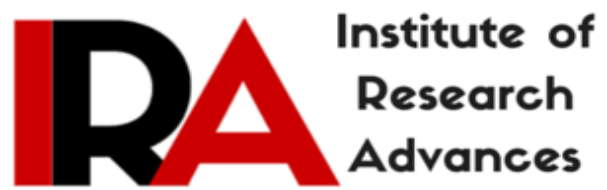

\title{
Toxicity Evaluation of Pesticide Industry Wastewater through Fish Bioassay
}

\author{
${ }^{1}$ Dr. Mrinmayi Chavan, ${ }^{2}$ Dr. N. P. Thacker, ${ }^{3}$ Dr. J. L. Tarar \\ ${ }^{1}$ Assistant Professor, Dr. Ambedkar Institute of Management Studies \& Research, \\ Nagpur, India \\ ${ }^{2}$ Former Scientist \& Head, National Environmental Engineering Research Institute, \\ Nagpur, India. \\ ${ }^{3}$ Former Head of Dept., Institute of Science, Nagpur, India.
}

DOI: http://dx.doi.org/10.21013/jas.v3.n3.p3

\section{How to cite this paper:}

Chavan, D., Thacker, D., \& Tarar, D. (2016). Toxicity Evaluation of Pesticide Industry Wastewater through Fish Bioassay. IRA-International Journal of Applied Sciences (ISSN 2455-4499), 3(3). doi:http://dx.doi.org/10.21013/jas.v3.n3.p3

(C) Institute of Research Advances

(cc) EY-NC

This works is licensed under a Creative Commons Attribution-Non Commercial 4.0 International License subject to proper citation to the publication source of the work.

Disclaimer: The scholarly papers as reviewed and published by the Institute of Research Advances (IRA) are the views and opinions of their respective authors and are not the views or opinions of the IRA. The IRA disclaims of any harm or loss caused due to the published content to any party. 


\section{ABSTRACT}

Besides pesticides contamination from agricultural field, the agricultural industries are also contributing by relatively high quantities of toxic pesticides into the environment. Considering the high pollution potential of the Pesticide formulation industry which is one of the main point sources of water pollution, toxicity study was conducted. In this study, the toxicity of the wastewater before and after preliminary treatment is checked using fish bioassay on Lebistus reticulate, with the analysis of physicochemical parameters and OCPs concentration. The results indicated exceeding values of the physicochemical parameters than the guideline values $(C P C B)$. Wastewater exerted more toxicity due to the presence of high OCPs i.e. $1.719 \mathrm{mg} / \mathrm{l}$; equally sulphide concentration was $17.60 \mathrm{mg} / \mathrm{l}$ which is also higher compared to stipulated standard of $2.0 \mathrm{mg} / \mathrm{l}$, which causes odor to the surrounding environment. It also contained oil/grease up to $80 \mathrm{mg} / \mathrm{l}$. Treated wastewater was also detected with the concentration $(0.587 \mathrm{mg} / \mathrm{l})$ of OCPs higher than the standard values prescribed by $C P C B$ for the pesticide industry effluent discharge. The study inferred that raw wastewater was very toxic to the fish Lebistus reticulate whereas, preliminary treatment to the effluent had reduced toxicity to certain extent, but it doesn't solve a purpose and hence needs correction in the pretreatment method.

Keywords: Toxicity, bioassay, pesticide, wastewater, effluent.

\section{Introduction}

Mostly pesticides are used in three sectors viz. agriculture, public health and consumer use. By and large industrial use of pesticide is of vital importance in the industries such as wood and carpet, wood preservation, etc. The consumption of pesticides in India is about $600 \mathrm{~g} /$ hectare, whereas that of developed countries is touching $3000 \mathrm{~g} / \mathrm{hectare}$. There are about 150 industrial units manufacturing pesticides (technical) and about 500 industrial units engaged in formulations in the country. India is the largest producer of pesticides in Asia and ranks twelfth in the world for the use of pesticides (EPA report on pesticide industry).

The pesticides are produced in two stages the manufacture of pesticide and the formulation of the final product. Most of the pesticide processes are batch processes and the remaining are continuous processes. Because of the nature of pesticides and their components, wastewater generated from manufacturing plants usually has a toxic nature. Washing and cleaning operations provide the principal sources of wastewater in formulating and packaging operations. Because these primary sources are associated with cleanup of spills, leaks, area wash downs and storm water runoff. Wastewaters from formulation and packaging operations typically have low levels of $\mathrm{BOD}, \mathrm{COD}$, TSS and $\mathrm{pH}$ is generally neutral. In the past, evaporation was the predominant disposal technique for wastewater generated in formulating plants. Although, the formulating industries are permitted to discharge the treated effluent to the surface water bodies after fulfilling the Effluent standards for Pesticide industry prescribed by CPCB (Central Pollution Control Board, India). Considering the high pollution potential of the Pesticide formulation industry which is one of the main point sources of water pollution, toxicity study was conducted.

Biological tests are necessary for studying the toxicity and biochemical effects of pesticides to individual species in the animal and plant kingdoms as well as for indirect determination of biologically important physical and chemical properties of 
pesticides. Some of the more important requisites for meaningful application of biological tests are careful method standardization; use of sensitive sub-lethal indicators of toxicity; detailed knowledge of the life cycle and the environmental requirements of organisms; and proper interpretation and limitation of use of the data engendered.

"Bioassay signifies a test in which a living tissue, organism or a group of organisms is used as test material for the determination of the potency of any physiologically active substance of unknown activity". Some workers prefer the term "Toxicity test" rather than bioassay. (FAO, 1977)

Bioassay studies for effluents from wastewater treatment plants provides a complete response of test organisms to compounds present in wastewater and to understand the discharge capacity of the raw and treated wastewaters (Shrinivas et al., 1984; Movahedian et al., 2005). Many industrial effluents have been used for toxicity evaluation on different fresh water fishes (Klein 1977; Kumar et al., 1995; Vanerkar et al., 2004). In recent years more attention is being given to acute toxicity evaluation for industrial effluents due to the imposition of stringent laws on discharge standards (Maleki et al., 2005). Fish has been considered as useful index for the purity of water and no river should be considered in a satisfactory condition unless fishes thrive well in it (Klein 1977).

\section{Materials and methods}

\subsection{Pesticide industry wastewater}

Nagpur has most of the pesticide industries engaged in formulation of pesticides in proportion to the manufacturing units. The effluent (wastewater) sample used for the present investigations was collected from a Pesticide industry engaged in formulation of OCPs (Organochlorine pesticides) and OPs (Organophosphates); located in Nagpur district in Maharashtra state of India. Most of the waste from this industry is of dry (dust) because of the incineration process, the sample collected was mostly from the spills, leaks, area wash downs. Wastewater before and after preliminary treatment were collected on hourly basis for 24 hours and composited as per flow on $8^{\text {th }}$ March, 2013. Samples were stored in a $4^{0} \mathrm{C}$ refrigerator until transported to the laboratory (on wet ice) for analysis, to perform the toxicity test. Sampled raw effluent and treated effluent were characterized for important physicochemical parameters as per standard methods (BIS, 2009), presented in Table 1 . The heavy metals concentration (Table 2) was determined by Inductivity Coupled Plasma - Atomic Emission Spectrophotometer (ICP-AES): Jobin Yuon Model JY-24, France equipped with a computer, while the multi-elemental standards for the metals were procured from EMerk Germany. The determinations of pesticides residue in Table 3 had been performed following U.S. Environmental Protection Agency (USEPA), Method$8081 \mathrm{~B}$ and self-modified laboratory method using GC-SHIMADZU with ${ }^{63} \mathrm{Ni}$ Electron Capture Detector.

\subsection{Fish bioassay study}

The potential consequences of indirect as well as chronic (long-term) and delayed effects of the waste on the water bodies through the toxicity test were assessed by conducting $96 \mathrm{hrs}$ bioassay test. The test organism for the study was selected according to the criteria for the selection of test organisms of United States Environmental Protection Agency (USEPA, 1979). Static bioassay tests were conducted at room temperature using fish Poecilia Libestes Reticulata (Guppy fish) as test organism. This fish was used for the experiments based on their easy 
availability and being sturdier in nature. Healthy specimens were chosen for the experiments with length and weight of the fish, ranged between 1.5-2.0 inches and $15-25 \mathrm{~g}$ respectively. Fishes required for the study were procured from local pond and toxicity evaluation was followed as cited in the literature (Doudoroff et al. 1951; Sprague 1969; APHA, $22^{\text {nd }}$ edition, 2012). The dilution water for bioassay studies was prepared from the tap water after de-chlorination by passing through a column of GAC (Granular activated carbon) and aerated to keep the dissolved oxygen at saturated level. Bioassay study was carried out in 10 liter glass aquaria using 10 fishes in each dilution. Fishes were stored for 48 hours prior to start of the experiment. The test fish were exposed to fresh test solution of similar concentration once in every 24 hrs by replacing the test solution. The total number of dead fishes was recorded every 48 and $96 \mathrm{hrs}$ and fish was considered to be dead when it did not respond to external stimuli. The test was conducted for different concentrations of the sample (range finding bioassay).

\section{Result and discussion}

The physicochemical characterization, heavy metals and pesticide residues concentration of the wastewater with the CPCB effluent standards (2007-08) is presented in Table 1, 2 and 3, respectively. The toxicity data for the wastewater is presented in Table 4 . The toxicity of wastewater was evaluated with the help of static bioassay tests for 96h, according to method recommended by American Public Health Association (APHA, 2012). The concentrations at which 50\% of test animals were able to survive (96h LC50) were calculated by subjecting the data to probit analysis (Finney, 1971). The results obtained were subjected to statistical evaluation and to confirm the authenticity of the experiments median tolerance limit ( $\mathrm{TL}_{50}$ values) or Lethal Concentration $\left(\mathrm{LC}_{50}\right)$, slope function and regression coefficient $\left(\mathrm{R}^{2}\right)$ were calculated as is indicated in Figure 1. Safe application rate (SAR) was calculated by using following formula given by Basak and Konar (1977):

Safe Application Rate $=$ LC0 $\times$ LC50 / LC100

Table 1. Physicochemical characteristics of raw wastewater and treated wastewater

\begin{tabular}{|l|l|c|c|c|}
\hline $\begin{array}{l}\text { Sr. } \\
\text { No. }\end{array}$ & Test parameter & $\begin{array}{c}\text { Raw } \\
\text { wastewater }\end{array}$ & $\begin{array}{c}\text { Treated } \\
\text { wastewater }\end{array}$ & $\begin{array}{c}\text { CPCB } \\
\text { effluent } \\
\text { standards }\end{array}$ \\
\hline 1 & $\mathrm{pH}$ & $\begin{array}{c}6.37 \text { at } \\
27^{\circ} \mathrm{C}\end{array}$ & 7.4 & $6.5-8.5$ \\
\hline 2 & Colour & $\begin{array}{c}\text { Light } \\
\text { brown }\end{array}$ & Yellow & - \\
\hline 3 & $\begin{array}{l}\text { Electrical conductivity at } 25^{\circ} \mathrm{C} \\
\mu \text { s/cm }\end{array}$ & 222.70 & 196.30 & - \\
\hline 4 & Total solids & 300 & 200 & - \\
\hline 5 & Total suspended solid (TSS) & 80 & 70 & 100 \\
\hline 6 & Total Nitrogen & 25.45 & 20.00 & 50.00 \\
\hline 7 & Oil and Grease & 80 & 20 & 10 \\
\hline 8 & Sulphides & 17.60 & 15.00 & - \\
\hline 9 & $\begin{array}{l}\text { Chemical oxygen demand } \\
\text { (COD) }\end{array}$ & 304 & 140 & 150 \\
\hline 10 & $\begin{array}{l}\text { Biological oxygen demand } \\
(B O D)\left(27^{\circ} \mathrm{C} \text { for } 3 \text { days }\right)\end{array}$ & 64.80 & 34.00 & 30.00 \\
\hline
\end{tabular}




\begin{tabular}{|l|l|c|c|c|}
\hline 11 & DO & 1.80 & 5.75 & - \\
\hline 12 & Chlorides (as Cl) & 27.40 & 20.14 & - \\
\hline
\end{tabular}

All values are expressed as $\mathrm{mg} / \mathrm{l}$ except $\mathrm{pH}$, colour and conductivity

Table 2. Heavy metals concentration in aw wastewater and treated wastewater $(\mathrm{mg} / \mathrm{l})$

\begin{tabular}{|c|c|c|c|c|}
\hline Sr. No. & Heavy Metals & $\begin{array}{l}\text { Raw waste } \\
\text { water }\end{array}$ & $\begin{array}{c}\text { Treated } \\
\text { wastewater }\end{array}$ & $\begin{array}{l}\text { CPCB effluent } \\
\text { standards }\end{array}$ \\
\hline 1 & $\mathrm{Al}$ & 0.360 & 0.245 & - \\
\hline 2 & $\mathrm{Cd}$ & 0.182 & 0.045 & - \\
\hline 3 & Co & 0.220 & 0.157 & - \\
\hline 4 & $\mathrm{Cr}$ & 0.283 & 0.190 & - \\
\hline 5 & $\mathrm{Cu}$ & 0.135 & 0.080 & 1 \\
\hline 6 & $\mathrm{Fe}$ & 0.806 & 0.562 & - \\
\hline 7 & $\mathrm{Mn}$ & 0.286 & 0.145 & 1 \\
\hline 8 & $\mathrm{Ni}$ & 0.326 & 0.252 & $\begin{array}{l}\text { Shall not exceed five } \\
\text { times the drinking water } \\
\text { standard of BIS (i.e. 45) }\end{array}$ \\
\hline 9 & $\mathrm{~Pb}$ & 0.635 & 0.345 & - \\
\hline 10 & $\mathrm{Zn}$ & 0.423 & 0.311 & 1 \\
\hline
\end{tabular}

Table 3. OCPs concentration in aw wastewater and treated wastewater $(\mathrm{mg} / \mathrm{l})$

\begin{tabular}{|c|c|c|c|c|}
\hline Sr. No. & Heavy Metals & $\begin{array}{l}\text { Raw } \\
\text { wastewater }\end{array}$ & $\begin{array}{l}\text { Treated } \\
\text { wastewater }\end{array}$ & $\begin{array}{l}\text { CPCB effluent } \\
\text { standards }\end{array}$ \\
\hline 1 & $\alpha \mathrm{HCH}$ & 0.065 & 0.020 & - \\
\hline 2 & $\beta \mathrm{HCH}$ & 0.117 & 0.031 & - \\
\hline 3 & $\gamma \mathrm{HCH}$ & 0.891 & 0.342 & - \\
\hline 4 & $\delta \mathrm{HCH}$ & 0.051 & 0.032 & - \\
\hline 5 & $\sum \mathbf{H C H}$ & 1.124 & 0.425 & 0.10 (other OCPs) \\
\hline 6 & Aldrin & 0.136 & 0.089 & 0.10 (other OCPs) \\
\hline 7 & Endo-SO $_{4}$ & 0.079 & 0.047 & 0.01 \\
\hline 8 & p p'-DDE & - & - & - \\
\hline 9 & o p'-DDD & 0.517 & 0.015 & - \\
\hline 10 & $\sum$ DDT & 0.517 & 0.115 & 0.01 \\
\hline
\end{tabular}

CPCB, 2007-08 
Table 4. Toxicity data for the raw wastewater of the pesticide industry

\begin{tabular}{|r|l|c|c|}
\hline $\begin{array}{r}\text { Sr. } \\
\text { No. }\end{array}$ & $\begin{array}{l}\text { Concentration of raw } \\
\text { wastewater with dilution, \% } \\
\text { by volume }\end{array}$ & $\begin{array}{l}\text { Survival of fishes (in the exposure } \\
\text { period) }\end{array}$ & $\mathbf{4 8 ~ h r s}$ \\
\cline { 3 - 4 } & $30 \%$ (As such) & 0 & 0 \\
\hline 2. & $25 \%$ (As such) & 0 & 0 \\
\hline 3. & $\begin{array}{l}10 \% \text { Aerated for 2 hrs (DO = } \\
8.2 \text { ) }\end{array}$ & 0 & 0 \\
\hline 4. & $\begin{array}{l}5 \% \text { sample after removing } \\
\text { suspended solids }\end{array}$ & $75 \%$ & 0 \\
\hline 5. & $5 \%$ (As such) & $75 \%$ & $60 \%$ \\
\hline 6. & $2.5 \%$ (As such) & $90 \%$ & $95 \%$ \\
\hline 7. & $1 \%$ (As such) & $100 \%$ & \\
\hline
\end{tabular}

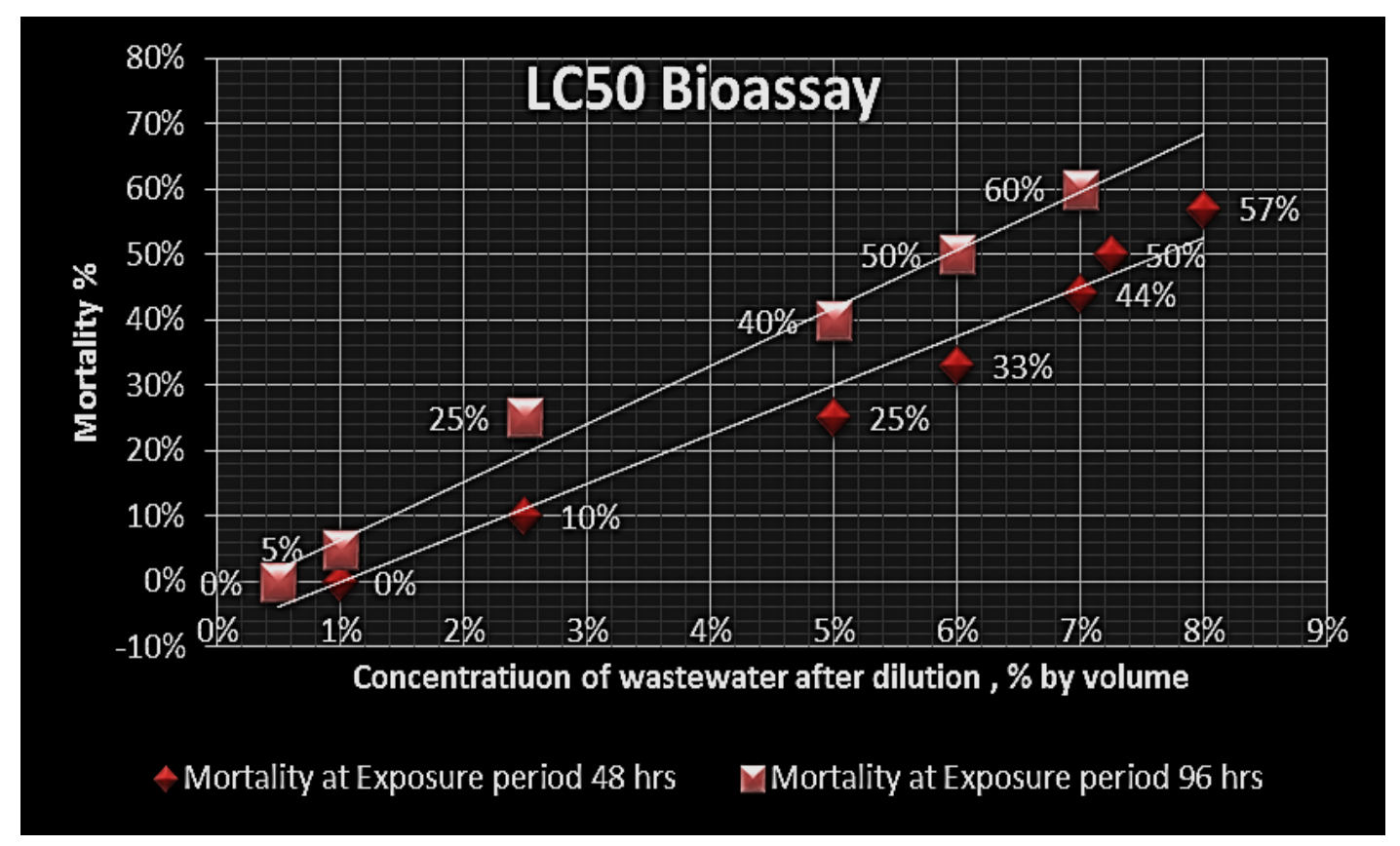

Figure 1. Response curve for obtaining $48 \mathrm{hrs} \& 96 \mathrm{hrs} \mathrm{LC}_{50}$ of raw wastewater 
Table 5. Statistical values of $96 \mathrm{hr}$ static bioassay of raw wastewater

\begin{tabular}{|c|l|l|}
\hline Sr. No. & Statistical parameters & Values \\
\hline 1. & $\mathrm{LC}_{50}(\mathrm{v} / \mathrm{v})$ & $6 \%$ \\
\hline 2. & S.E. (Standard error) & 0.035 \\
\hline 3. & Regression equation & $\mathrm{y}=8.8914 \mathrm{x}-0.026$ \\
\hline 4. & Regression coefficient & 0.9871 \\
\hline 5. & SAR (Safe Application Rate) & $0.259 \%$ \\
\hline
\end{tabular}

Wastewater from pesticide manufacturing industries originates from cleaning activities after batch operation during the synthesis process. They may contain toxic organics and pesticide residues which pose a threat to the quality of surface and groundwater. Wastewater from agricultural industries and pesticide formulation and manufacturing plants were reported to have pesticide contamination levels as high as $500 \mathrm{mg} / \mathrm{l}$ (Chiron, 2000). Wastewater therefore contains all the unconverted raw materials and the intermediate products in different stages and finally form a cocktail mixture of these compounds dissolved in the solvents. The wastewater also contains variety of trace metals that happens to have entered due to the reaction of wastewater with storage containers and metal pipes and fittings. Apart from the above substances gel, oil and grease is also generated.

Raw wastewater that is generated during the formulation process of pesticides was quite strong waste as observed from the physicochemical characterization, indicated in Table $1 \& 2$. All the physicochemical parameters exceeded the guideline values (CPCB). It exerted more toxicity due to the presence of high OCPs i.e. $1.719 \mathrm{mg} / \mathrm{l}$; equally sulphide concentration was $17.60 \mathrm{mg} / \mathrm{l}$ which is also higher compared to stipulated standard of $2.0 \mathrm{mg} / \mathrm{l}$, which causes odor to the surrounding environment. It also contained oil/grease up to $80 \mathrm{mg} / \mathrm{l}$.

Treated wastewater was also detected with the concentration $(0.587 \mathrm{mg} / \mathrm{l})$ of OCPs higher than the standard values prescribed by CPCB for the pesticide industry effluent discharge. Besides, the bioassay test for treated water resulted in $75 \%$ survival of fish after $96 \mathrm{hrs}$. in 100\% effluent; which is less than the prescribed standard which expects $90 \%$ survival of fish after $96 \mathrm{hrs.} \mathrm{in} \mathrm{100 \%} \mathrm{effluent.} \mathrm{Sulphide}$ concentration in treated wastewater was $15 \mathrm{mg} / \mathrm{l}$, with the oil/grease concentration up to $25 \mathrm{mg} / \mathrm{l}$. It makes a coat on the gills of fish creating respiratory problems. Surface layer of floating oil reduces the dissolved oxygen content of the water. All these parameters would impart toxicity to fish; hence toxicity evaluation through fish bioassay was carried out to arrive at a dilution factor for raw wastewater prior to its discharge into surface water bodies. The fish Libestes Reticulata is supposed to be very sturdy in nature but during the toxicity tests it exhibited different degrees of susceptibility to the various concentrations of wastewater. However LC50 values still provide information for the gross comparison of toxicity of the pollutants to fishes. During the acute toxicity test the fish exhibited several type of reactions, for instance raw wastewater, which depicted more toxicity, made the fish more restless immediately after the addition of the wastewater. They came to the surface of the water to gulp the air at initial stages. Quick opercula movements were observed initially and after few hours they started slow movements and finally the fishes became calm and settled at the bottom of test chamber. Loss of balance was observed in case of all experimental fishes whereas, in case of raw wastewater, body of fish became dark and body bending was seen.

From the LC50 values as indicated in Table 5, it is clear that the raw wastewater exerts more toxicity. Electrochemical treatment methods have been reported to be quite efficient in eliminating toxicity of the organics due to its structural modification. 
However, it is also likely that the intermediates after treatment are more toxic than the parent substances. Also, presence of high chlorides content in raw wastewater, could lead to formation of organochorinated by-products after the electrochemical treatment.

LC50 values for raw and treated wastewater did not show wide variation indicating toxic nature of the wastewater and treated effluent. The regression coefficient $\left(\mathrm{R}^{2}\right)$ 0.9871 indicates high correlation between \% concentration and \% mortality. Apart from 96 hours LC50, full range of lethal concentration (LC0 - LC100) was taken into consideration while assessing the susceptibility of an organism to toxic effluent. SAR (Safe Application Rate) was calculated on the basis of $96 \mathrm{hr}$. acute toxicity tests resulted as $0.259 \%$.

\section{Discussion}

The results provide baseline information in formulating strategy for controlled release of treated pesticide industry effluents into the receiving water bodies. For application of toxicity data in regulation of wastewater discharges and prediction of environmental affects both acute and chronic toxic levels have to be determined to conserve aquatic life. Therefore, from the studies it can be inferred that raw wastewater is very toxic to the fish Lebistus reticulata whereas, preliminary treatment to the effluent had reduced toxicity to certain extent, but it doesn't solve a purpose as it also exceeds the prescribed standard limits at the maximum. SAR of wastewater was $0.259 \%$ for Lebistus reticulata. This showed that wastewater was not safe for disposal in the concentrations higher than calculated SAR. So, the study indicates the need for corrections in pretreatment of effluent to bring it to the standards and to make it safe for disposal in aquifer (surface water body).

\section{References}

1. APHA, AWWA, WEF, (2012), Standard Methods for examination of water and wastewater. $22^{\text {nd }}$ ed. Washington: Americ an Public Health Association. 1360 pp. ISBN 978-087553-013-0.

2. Basak P. K. and Konar S. K. (1977), Estimation of safe concentration of insecticides, a new method tested on DDT and BHC. J. Inland Fish. Soc. India. 9: 9-29.

3. Bureau of Indian Standards (2009), Indian standard methods of sampling and test (physical and chemical) for water and wastewater, IS 3025 (Part 21): 2009.

4. Central Pollution Control Board (2007-08), Standards for Emission or Discharge of Environmental Pollutants from pesticide manufacturing and formulation industry (New revised standards), available at www.cpcb.nic.in, accessed during April 2013.

5. Chiron S., Fernandez-Alba A., Rodriguez A. and Garcia-Calvo E., (2000), Pesticide chemical oxidation: State-of-the-art. Water Res., 34(2), 366-377.

6. Doudoroff P., Anderson B.G., Burdick G.E., Galtsaff P.S., Hart W.B., Patrick E.R., Strong E.R., Surbes E.W. and Vanitron W.M., (1951), Bioassay methods for the evaluation of acute toxicity of industrial wastewater to fish. Sewage \& Ind. Wastes, 23: 130-136. 
7. FAO (1977), Manual of methods in aquatic environment research. Part 4. Bases for selecting biological tests to evaluate marine pollution. FAO Fish. Tech. Pap., 164: $31 \mathrm{Pp}$.

8. Finney D. J., (1971), Probit analysis, 3rd Ed. Cambridge University Press, Cambridge. p. 333. http://www.standardmethods.org/

9. Klein S. A. and Jenkins D., (1977), Environmental quality research, fish and aufwuchs bioassay. AMRL-TR-77-54, Aerospace Medical Research Laboratory, Wright-Patterson AFB, Ohio.

10. Kumar S., Sahay S.S., Sinha M.K., (1995), Bioassay of common distillery effluent on common guppy Lebistes Recticulatus (Peter). Bull. Environ. Contamin. \& Toxicol., 54: 309-316.

11. Leeuwen C. J. Van and Vermeire T.G., )2007(, Risk assessment of chemicals: An introduction, second edition, published by Springer. ISBN 978-1-4020-6102-8 (ebook).

12. Maleki A., Mahvi A. H., Vaezi F. and Nabizadeh R., (2005), Ultrasonic degradation of phenol and determination of the oxidation by-products toxicity, Iranian J. of Environ. Health Sci. \& Eng., 2(3): 201-206.

13. Movahedian H., Bina B. and Asghari G.H., (2005), Toxicity evaluation of wastewater treatment plant effluents using Daphnia Magna, Iranian J. of Environ. Health Sci. \& Engg, 2(2): 1-4.

14. Shrinivas P., Banerji G., Rao P., (1984), Preliminary observations on the effect of industrial effluents to certain animals, Ind. Journal of Environ. and Health, 26(1): 57-59.

15. Sprague J.B., (1969), Review paper: Measurement of pollutant toxicity to fish 1Bioassay methods for acute toxicity, Water Res., 3: 793-796.

16. Vanerkar A.P., Satyanarayan S. and Dharmadhikari D.M., (2004). Toxicity of herbal bulk drug industry wastewater on fish- lebistes reticulatus (peter), J. of Environ. Sci. and Health, B39 (1): 115-123. 